\title{
Intelligent information systems
}

UDC 621.384

doi: 10.20998/2522-9052.2019.1.17

\author{
E. Gryshmanov ${ }^{1}$, T. Kalimulin ${ }^{2}$, I. Zakharchenko ${ }^{2}$ \\ ${ }^{1}$ Flight Academy of National Aviation University, Kropyvnytskyi, Ukraine \\ ${ }^{2}$ Ivan Kozhedub Kharkiv National Air Force University, Kharkiv, Ukraine
}

\section{PROGNOSIS METHOD OF UNFAVORABLE AIRBORNE EVENTS DURING FLIGHT BASED ON CONVOLUTIONAL AND RECURRENT NEURAL NETWORKS}

\begin{abstract}
This paper contains formal problem definition of predicting unfavorable airborne events during flight. Restrictions and assumptions are put into the prognosis method of unfavorable airborne events during flight. Mathematical apparatus used to build prognosis method is suggested. As a basic mathematical apparatus it is suggested to use, recurrent neural networks (RNN) based on LSTM modules and convolutional neural networks (CNN). Analysis of these neural networks has shown that RNN based on LSTM modules are mostly effective when analyzing structured text, such as report of investigation of airborne accidents. In its turn, $\mathrm{CNN}$ are effective when analyzing unstructured text, such as text messages about the flight situation based on the information from external sources. Prognosis method of unfavorable airborne events during flight based on convolutional and recurrent neural networks is developed. In case of solving the task of prediction of unfavorable airborne events during flight RNN are used for initial setup of the Embedding layer of the structured training data in the process of hybrid neural network training. $\mathrm{CNN}$ are used during the direct operation of hybrid neural network model of prediction of unfavorable airborne events during flight.
\end{abstract}

Keywords: deep neural network; convolutional neural network; recurrent neural network; prognosis; unfavorable airborne event; hyperparameter; accuracy factor.

\section{Introduction}

Problem statement. From different reports and researches on airborne events it is clear that civil aviation flight's safety is unsatisfactory [1-3]. Automatization of the prognosis of unfavorable airborne events during flight based both at the ground control post and at the aircraft is one of the modern approaches to solve the problem how to increase flight's security. With this, emphasis is made on use of right processes of methods and models of artificial intelligence for formalization of these reports, especially with methods and models based on deep neural networks.

Among other things, this paper recommends to use convolutional and recurrent neural networks within the framework of deep neural network to formally represent the processes of solving the task of prognosis of unfavorable airborne events during flight [4-9]. The prognosis of the rapid emergence of airborne event of some class is recommended to be examined as an analysis of text messages, being formed on results of data, gathered from different sources during air traffic control. Learning pattern and function of deep neural network has special meaning for quality prognosis. Simultaneously, usage of networks of this class to predict unfavorable airborne events during flight are underexamined. At this context, the paper introduces the prognosis method of unfavorable airborne events during flight based on convolutional and recurrent neural networks.

Actual scientific researches and issues analysis. The problem of automatization of solving the task of preventing airborne events is mentioned in literature quite often and many works are dedicated to it [10-12]. For example, paper [13] examines in detail question of designing the system that predicts and prevents airborne events during organization and process of air traffic. With this, question of usage of deep neural networks to solve the task of prognosis and prevention of unfavorable airborne events during flight are underexamined and require further researches.

Purpose of the article. Development of prognosis method of unfavorable airborne events during flight based on convolutional and recurrent neural networks.

\section{Main part}

Formally, the task of prognosis of unfavorable airborne events can be represented as follows. It is required to create a $N$ classifier, which will predict the initiation of airborne accident of some class $K_{S}$. The analysis, made in paper [13], shows that the chain that leads to the airborne event includes next main elements:

- exposure of factors $\left(H_{i}\right)$, which are an initiating event for the airborne accident;

- an intermediate event $\left(E_{\ell}\right)$;

- escalation, that leads to the end-state event $\left(I_{j}\right)$ of the airborne accident.

In this case, the result of the prognosis can be depicted as

$$
F_{a c c}:\left\{K_{s}\right\} \rightarrow\left(\left\{H_{i}\right\},\left\{E_{\ell}\right\},\left\{I_{j}\right\}\right) .
$$

The process of prognosis of unfavorable airborne event of some class itself in this work recommended to be examined as an analysis of text messages, being formed on results of data, gathered from different sources during air traffic control. In this setting, analysis of text messages consists of picking up key words which describe elements $H_{i}, E_{\ell}, I_{j}$, followed by automatic definition of possibility of initiation of airborne event of defined class $K_{S}$. 
The airborne event is formally depicted as following finite sequence

$$
\text { ACC }_{k}=\left(\begin{array}{c}
K_{s}, \text { Date }_{k}, \text { Time }_{k}, \text { Country }_{k}, \text { Place }_{k}, \\
\text { TypeAir }_{k}, \text { Reg }_{k}, \text { Airline }_{k}, \text { Flight }_{k}, \\
\left(\left\{H_{i}\right\} \cup\left\{E_{\ell}\right\} \cup\left\{I_{j}\right\}\right)
\end{array}\right\rangle,
$$

where $K_{s}$ - class of an airborne event; Date $_{k}$ - date of an airborne event; Time $_{k}$ - time of an airborne event; Country $_{k}$ - country, where airborne event happened; Place $_{k}$ - place of an airborne event; TypeAir ${ }_{k}$ - type of aircraft; $\operatorname{Reg}_{k}$ - aircraft registration; Airline $_{k}$ - airline, which was operating aircraft; Flight $_{k}$ - flight number; $\left\{H_{i}\right\} \cup\left\{E_{\ell}\right\} \cup\left\{I_{j}\right\}$ - description of an airborne event.

Restrictions and assumptions adopted during the development of prognosis method of unfavorable airborne events during flight:

- questions of gathering, processing and forming text messages for prognosis of unfavorable airborne events during flight are taken as solved and are not examined in this work;

- this work takes as a text message both unstructured and structured set of data organized as short sentences with a big number of learning examples;

- developed prognosis model can be used either during situational air traffic control $\left(\left\{H_{i}\right\} \cup\left\{E_{k}\right\}\right)$, or for classification of unfavorable airborne events during flight that have already happened, during their investigation $\left(\left\{H_{i}\right\} \cup\left\{E_{k}\right\} \cup\left\{I_{j}\right\}\right)$.

Deep neural networks (convolutional neural network $(\mathrm{CNN})$ and recurrent neural network (RNN) with LSTM blocks) are used as methods to develop a model of prognosis of unfavorable airborne events during flight based on the analysis of text messages.

Nowadays, CNN are considered highly effective when analyzing unstructured text. In the context of solving the problem of prognosis of unfavorable airborne events during flight this type of network is effective when using it in function of hybrid neural network model of prognosis of unfavorable airborne events during flight when unstructured data is the input data. With this, trained beforehand layer Embedding, based on structured learning data as a vector layer.

RNN based on LSTM modules are considered mostly effective first of all when analyzing structured text. In the context of solving the problem of prognosis of unfavorable airborne events during flight these networks are effective for initial setup of Embedding layer based on learning data when training hybrid neural network model of prognosis of unfavorable airborne events during flight. Common structure of method of prognosis of unfavorable events during flight based on hybrid neural network model with use of convolutional and recurrent neural networks is presented on the Fig. 1. This method includes next main procedures and methods:

1) Procedure of defining basic architecture of neural network model used for prognosis of unfavorable events during flight. The result of this procedure is fully determined by the results of the research of mathematical apparatus to develop a model of prognosis of unfavorable events during flight. According to the results of the research the architecture of the model for prognosis of unfavorable events during flight is based on hybrid model on the basis of $\mathrm{CNN}$, used for functioning of hybrid neural networking model of prognosis of unfavorable events during flight and LSTM, used for training hybrid neural networking model for prognosis;

2) Procedure of defining of hyperparameters for hybrid neural networking model for prognosis of unfavorable airborne events with use of $\mathrm{CNN}$ and LSTM;

3) Procedure of training of hybrid neural networking model and forming weight values for Embedding layer for prognosis of unfavorable airborne events during flight with learning data, received after use of method of learning data (this method is presented in [14]). With that, LSTM topology is used as base topology of neural network;

4) Procedure of building vector model of text messages from external sources during prognosis of unfavorable airborne events in flight. This procedure is similar to the procedure of building vector model of text messages on learning examples, which is executed when forming learning data [14];

5) Procedure of prognosis of unfavorable airborne events during flight based on function of trained hybrid neural network model with use of $\mathrm{CNN}$ and pre-trained layer of LSTM.

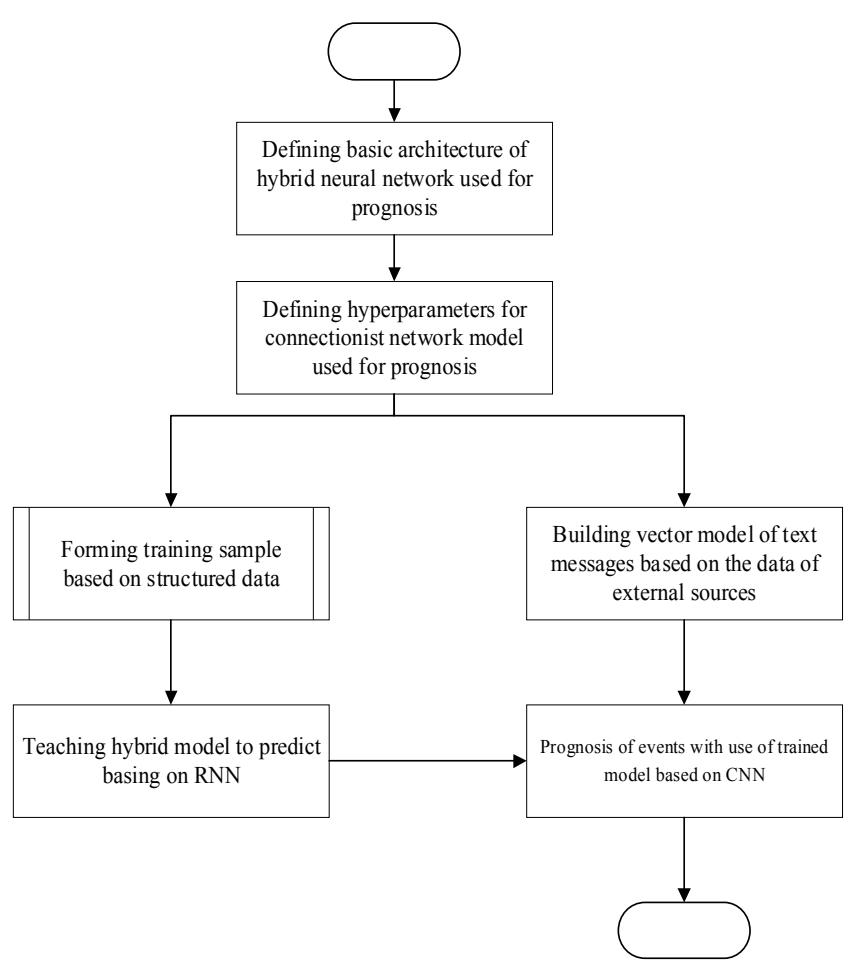

Fig. 1. Common structure of method of prognosis of unfavorable events during flight based on hybrid neural network model

It is recommended to consider next indicators as accuracy factors of prognosis: 
1. Index of precision - ratio of $t_{p}$ to $\left(t_{p}+f_{p}\right)$, where $t_{p}$ - number of true positive values and $f_{p}$ number of false positive values. This means that index of precision characterizes how many of received positive answers from the prognosis model are correct;

2. Index of completeness - ratio of $t_{p}$ to $\left(t_{p}+f_{n}\right)$, where $f_{n}$ - number of false positive values. Index of completeness defines prognosis model's capability to predict as many positive true answers as possible;

3. Support of measure - number of data for each of classes or smallest closed array, which this measure is focused on.

Let us look upon most complex and important procedures of training hybrid neural networking model for prognosis of unfavorable airborne events during flight with use of trained hybrid neural network model in details.

Training procedure for hybrid neuro networking model for prognosis of unfavorable airborne events is fully determined by training algorithm for neural network based on LSTM module. Structured data in a form of reports on results of investigation of unfavorable airborne events during flight (many training examples include 100 to 5000 learning examples) is used as learning data. Thereafter, based on transfer learning technology, to predict unfavorable airborne events during flight, Embedding layer, prepared beforehand is sent to $\mathrm{CNN}$ input. $\mathrm{CNN}$ continues to learn with use of learning data given as unstructured data about current situation during flight (in this case an array of learning examples may consist of 100 to 500 learning examples). The scheme of this procedure is presented as Fig. 2.

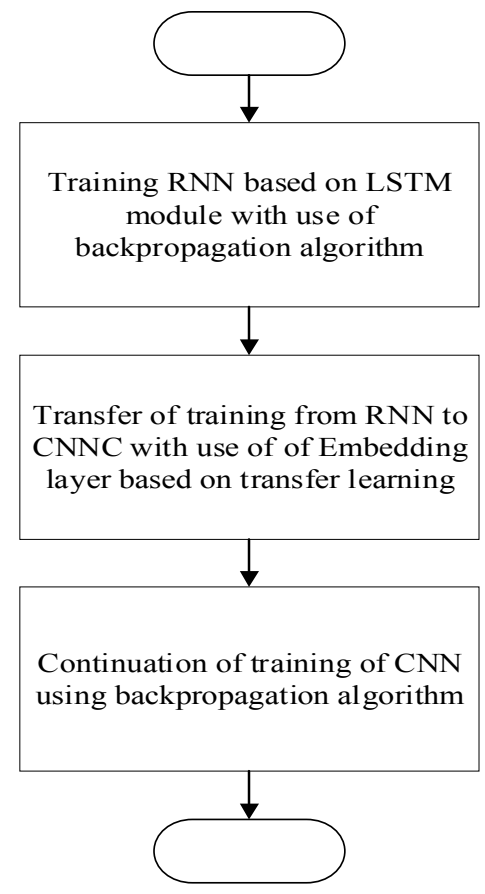

Fig. 2. Structural chart of realization of hybrid neural networking model for prognosis of unfavorable airborne events during flights
Training of RNN based on LSTM modules is similar to training classical neural network [6]. Thereby, as a basic training algorithm is used back propagation algorithm $[4,6]$. This algorithm is based on a principle, which allows calculating vector of partial derivatives (gradient) of the error function of network. Error function is a difference between current neural network's output value and wanted value, which has to be received. During training process, cascade compensations of weight quotients takes place and error function decreases stepwise.

The value of error function is weighed sum $L$ between localization error $L_{l o c}$ (for example, error Smooth L) and trust error $L_{\text {conf }}$ (for example, error softmax).

In RNN, because same parameters are used for all periods of time in the network, each gradient on the output depends not only from calculations of current step, but also from previous time steps. For example, to find gradient with $\mathrm{t}=4$, the error has to be spread over 3 steps and these gradients have to be summarized. This algorithm is known as Back propagation Through Time (BPTT).

What has also to be taken into account is that recurrent neural networks trained with BPTT have difficulties with training of longtime dependencies (for example when defining dependencies between steps, which are far away from each other) because of gradient dying-away.

Function and training of RNN based on LSTM modules are beased on realization of next stages:

- layer of vector representation of words Embedding converts each input (tensor of $k$ works) in tensor $k N$ - dimensional vector representations of words ( $N$ - size of representation);

- each word, typical for messages about the results of investigation on airborne events, is associated with weight vector, that has to be learned while training neural network;

- creation of tensor, that represents the message about the results of investigation on airborne events;

- immediate setup of LSTM wages is executed with use of RNN layers based on blocks of LSTM modules (with use of Dropout layer) while learning with use of BPTT. RNN layer is opening dynamically, receiving at the input of $k$ - vector representations and gives $M$-dimensional vectors, where $M-$ is a number of LSTM modules per block, in general case;

- vector Softmax is realizing output of RNN layer with averaging through $\mathrm{k}$ time steps. Tensor with $\mathrm{M}$ dimensions is formed to calculate possibilities for prognosis of unfavorable airborne events during flight.

Procedure of prognosis of unfavorable airborne events during flight with use of hybrid neural networking model is realized through execution of next operations (Fig. 3):

1) conversion of input words at the data layer as a three-dimensional array (tensor) $W_{\text {pict }} \times H_{\text {pict }} \times D_{\text {pict }}$, vector representation of words (vector model of text messages)based on the data from external sources;

2) realization of forward pass of CONV and ReLU layers. Number of CONV and ReLU layers is defined 
by architecture of $\mathrm{CNN}$ used for prognosis of unfavorable airborne events during flight;

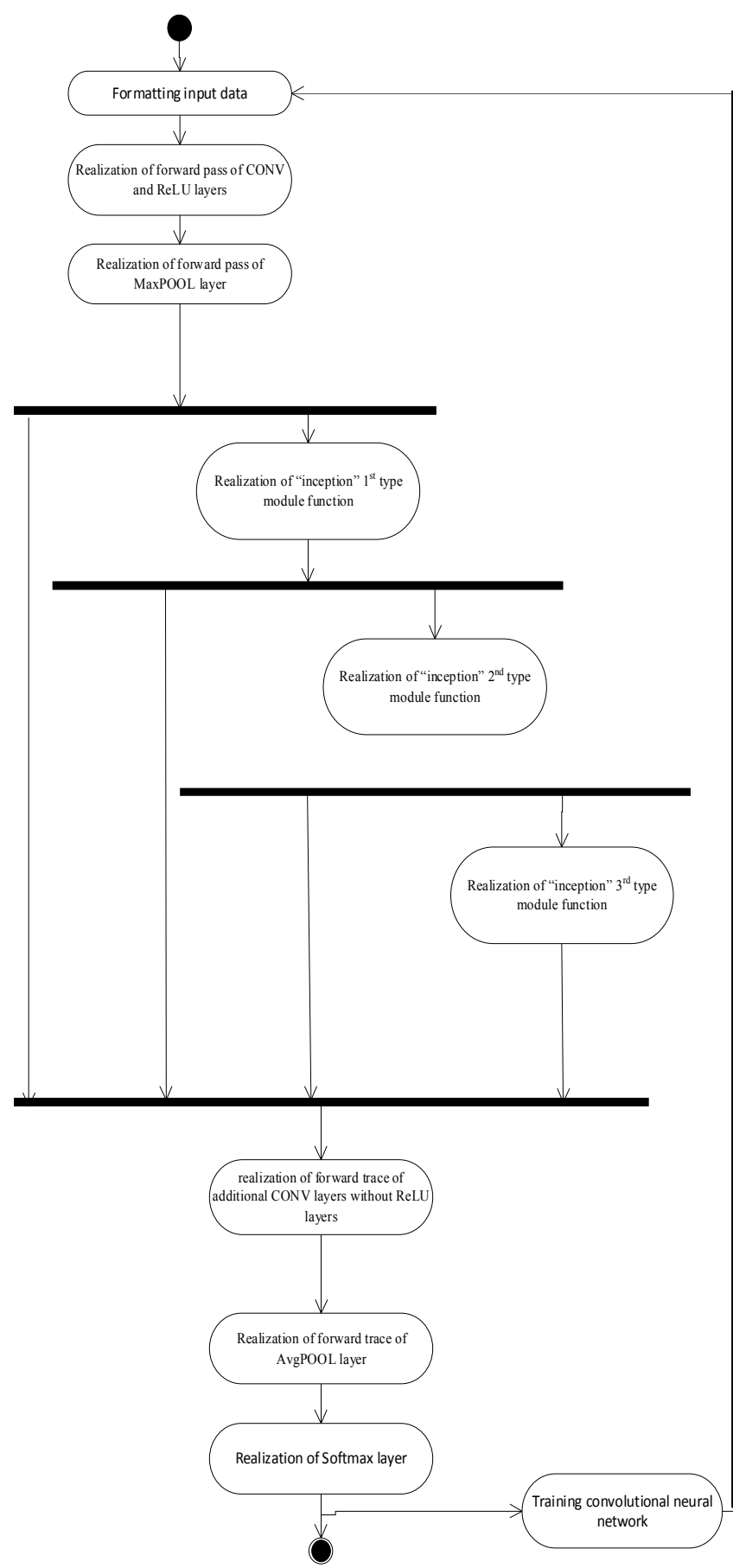

Fig. 3. Structural chart of prognosis of unfavorable airborne events during flight procedure
3) realization of forward pass of MaxPOOL layer in accordance to the architecture of $\mathrm{CNN}$ used for prognosis of unfavorable airborne events during flight;

4) realization of "inception" $1^{\text {st }}$ type module function which represents "network in network". Number of layers in "inception" $1^{\text {st }}$ type module is determined in accordance with CNN architecture;

$5)$ realization of "inception" $2^{\text {nd }}$ type module function which represents "network in network". Number of layers in "inception" $2^{\text {nd }}$ type module is determined in accordance with $\mathrm{CNN}$ architecture;

6) realization of "inception" $3^{\text {rd }}$ type module function which represents "network in network". Number of layers in "inception" $3^{\text {rd }}$ type module is determined in accordance with $\mathrm{CNN}$ architecture;

7) realization of forward trace of additional CONV layers without ReLU layers. Number of CONV layers is defined by features extraction subnet Fuzzy InceptionSSD;

8) realization of forward trace of AvgPOOL layer in accordance to $\mathrm{CNN}$ architecture;

9) feature maps, calculated on the output of AvgPOOL layer, are joined in one general layer of identifiers. It goes to input of hidden directly connected layer and then to the neural network output layer Softmax where resulting class markers for prognosis of unfavorable airborne events during flight are calculated.

\section{Conclusions}

Formal problem definition of prognosis of unfavorable airborne events during flight is completed. The process of prognosis of unfavorable airborne events during flight of some class is recommended to be examined as an analysis of text messages, being formed on results of data, gathered from different sources during air traffic control.

The analysis of text messages itself involves picking up key words followed by automatic definition of possibility of initiation of airborne event of defined class. Restrictions and assumptions adopted during the development of prognosis method of unfavorable airborne events during flight.

Use of developed method allows to provide effective prognosis of unfavorable airborne events during flight in future based on use of hybrid neural network.

Development of proposals to use computer facilities to realize process of prognosis of unfavorable airborne events during flight directly on the aircraft can be a direction for future research.

\section{REFERENCES}

1. Interstate Aviation Committee (2018), State of safety in civil aviation of the States Parties to the agreement on civil aviation and the use of airspace in the first half of 2018, Moscow, 29 p., available at: https://mak-iac.org/upload/iblock/5b0/bp-18-1.pdf.

2. Joyce A. (2014), Safety Report 2013, IATA, Montreal-Geneva, 60 p., available at: https://www.iata.org/about/documents/iata-annual-review-2013-en.pdf

3. BCA (2009), Statistical Summary of Commercial Jet Airplane Accidents, Worldwide Operations 1959-2008, Boeing Commercial Airplanes, Seattle, Washington 98124-2207, USA.

4. Britz, D. (2017), Understanding convolutional neural networks for NLP, available at: http://www.wildml.com/2015/11/ understanding-convolutional-neural-networks-for-nlp

5. Manning, C. and Socher, R. (2018), Natural language processing with deep learning, available at: http://web. stanford.edu/class/cs224n 
6. Olah, C. (2017), Neural networks, recurrent neural networks, convolutional neural networks, available at: http://colah.github.io

7. Sivaram, M., Porkodi, V., Mohammed, A.S. and Manikandan V. (2019), "Detection of Accurate Facial Detection Using Hybrid Deep Convolutional Recurrent Neural Network”, ICTACT Journal on Soft Computing, Vol. 09, Issue 02, pp.18441850, DOI: http://doi.org/10.21917/ijsc.2019.0256

8. Sivaram, M., Batri, K., Amin Salih, Mohammed and Porkodi V. (2019), "Exploiting the Local Optima in Genetic Algorithm using Tabu Search", Indian Journal of Science and Technology, Volume 12, Issue 1, doi: http://doi.org/10.17485/ijst/2019/v12i1/139577

9. Sivaram, M., Yuvaraj, D., Amin Salih, Mohammed, Porkodi, V. and Manikandan V. (2018), "The Real Problem Through a Selection Making an Algorithm that Minimizes the Computational Complexity", International Journal of Engineering and Advanced Technology, Vol. 8, Iss. 2, 2018, pp. 95-100.

10. Kuklev, E.A. (2003), "Evaluation of the level of safety of flights in civil aviation in risky situations based on chains of random events", Science and technology of transport, No. 2, pp. 4-14.

11. Sharov, V.D. (2011), "Methodology of application of the combined FMEA-FTA method for analyzing the risk of an aviation event”, Scientific Herald of MSTU GA, series “Air Transport Operation. Safety of flights”, No. 174, pp. 18-24.

12. Zubkov, B.V. (2010), Theory and practice of determining risks in airlines when developing a safety management system, MGTU GA, Moscow, 196 p.

13. Sharov, V.D. (2007), "Methodology for estimating the probability of aircraft rolling out of the runway during landing", Scientific Herald of MSTU GA, Series "Operation of air transport and repair of aviation equipment. Flight safety", No. 122, pp. 61-66.

14. Pavlenko, M., Shilo, S., Borosenets, I. and Dmitriev O. (2018), "Directions of development of intellectual models and methods of information processing for management of the information support process for decision-making in automated air traffic control", Control, navigation and communication systems, PNTU, Poltava, Vol. 5 (51), pp. 24-28.

Received (Надійшла) 16.01.2019

Accepted for publication (Прийнята до друку) 20.03.2019

\section{Метод прогнозування несприятливих авіаційних подій в польоті на основі згорткових і рекурентних нейронних мереж \\ Є. О. Гришманов, Т. Калімулін, І. В. Захарченко}

У даній роботі виконана формальна постановка задачі прогнозування несприятливих авіаційних подій в польоті. Введено обмеження і допущення при розробці методу прогнозування несприятливих авіаційних подій в польоті. Запропоновано математичний апарат для побудови моделі прогнозування несприятливих авіаційних подій в польоті. В якості базового математичного апарату запропоновано використовувати рекурентні нейронні мережі RNN на базі модулів LSTM і згорткової нейронної мережі CNN. Аналіз можливостей мереж показав, що RNN на базі модулів LSTM ефективні, насамперед, при аналізі структурованого тексту, в якості якого розглядаються звіти про результати розслідування авіаційних подій. У свою чергу CNN ефективні при аналізі неструктурованого тексту, в якості якого в роботі розглядаються текстові повідомлення про ситуації в польоті за даними від зовнішніх джерел. Розроблено метод прогнозування несприятливих авіаційних подій в польоті на основі згорткових і рекурентних нейронних мереж RNN в контексті вирішення завдання прогнозування несприятливих авіаційних подій в польоті використовуються для початкового налаштування прихованого шару на структурованих навчальних прикладах в процесі навчання гібридної нейромережевої моделі, CNN використовуються в процесі безпосереднього функціонування гібридної нейромережевої моделі прогнозування несприятливих авіаційних подій в польоті.

Ключові слова: глибока нейронна мережа; згорткова нейронна мережа; рекурентна нейронна мережа; прогнозування; несприятлива авіаційна подія; гіперпараметр; показник точності.

\section{Метод прогнозирования неблагоприятных авиационных событий в полете на основе сверточных и рекуррентных нейронных сетей}

Е. О. Гришманов, Т. Калимулин, И. В. Захарченко

В данной работе выполнена формальная постановка задачи прогнозирования неблагоприятных авиационных событий в полете. Введены ограничения и допущения при разработке метода прогнозирования неблагоприятных авиационных событий в полете. Предложен математический аппарат для построения модели прогнозирования неблагоприятных авиационных событий в полете. В качестве базового математического аппарата предложено использовать рекуррентные нейронные сети RNN на базе модулей LSTM и сверточные нейронные сети CNN. Анализ возможностей сетей показал, что RNN на базе модулей LSTM эффективны, прежде всего, при анализе структурированного текста, в качестве которого рассматриваются отчеты о результатах расследования авиационных происшествий. В свою очередь CNN эффективны при анализе неструктурированного текста, в качестве которого в работе рассматриваются текстовые сообщения о складывающейся ситуации в полете по данным от внешних источников. Разработан метод прогнозирования неблагоприятных авиационных событий в полете на основе сверточных и рекуррентных нейронных сетей. RNN в контексте решения задачи прогнозирования неблагоприятных авиационных событий в полете используются для первоначальной настройки скрытого слоя на структурированных обучающих данных в процессе обучения гибридной нейросетевой модели, CNN используются в процессе непосредственного функционирования гибридной нейросетевой модели прогнозирования неблагоприятных авиационных событий в полете.

Ключевые слова: глубокая нейронная сеть; сверточная нейронная сеть; рекуррентная нейронная сеть; прогнозирование; неблагоприятное авиационное событие; гиперпараметр; показатель точности. 